J. Clin. Chem. Clin. Biochem.

Vol. 21, 1983, pp. 481-489

\title{
Continuous Assay of Serum 5'-Nucleotidase Activity with Inosine 5'-Monophosphate as Substrate and Total Automation Using a Transfer-Analyzer (Kem-O-Mat)
}

\author{
By Eliane Stephant, Michèle Vernet-Nyssen \\ Laboratoire de Biochimie - Hôpital de la Croix-Rousse, Lyon, France and
}

Bénédicte Mousson

Laboratoire de Biochimie - Hôpital Debrousse, Lyon, France

(Received July 5, 1982/January 6, 1983)

Summary: The continuous spectrophotometric assay of 5'-nucleotidase originally described by Heinz et al. ((1980) J. Clin. Chem. Clin. Biochem. 18, 781-788) was modified and fully automated on a Kem-O-Mat transfer analyzer, using inosine $5^{\prime}$-monophosphate as substrate. The reaction product was hydrogen peroxide and the reduction of NADP was observed for 10 minutes at $340 \mathrm{~nm}$ and at a reaction temperature of $30^{\circ} \mathrm{C}$. The different factors involved in the enzyme reaction were checked, including the substrate concentration, reaction rate, linearity and substrate preservation. Normal values ranged from 1 to $13 \mathrm{U} / \mathrm{l}$. Between-day reproducibility was estimated with two different commercial control sera, and the coefficient of variation was $5 \%$ for the upper limit of normal activity $(23 \mathrm{U} / 1)$. There was good agreement between the present method and a semi-automatic colorimetric technique (for 100 sera tested by both methods, the correlation coefficient was 0.974 and the regression line equation, $y=0.85 x-1.5$ ). Despite the lengthy reagent mixture preparation procedure, the method permitted assay of 50 samples per hour. The occurrence of high serum blanks in certain pathological states is discussed.

Kontinuierliche Bestimmung der katalytischen Aktivität von 5'-Nucleotidase im Serum mit Inosin-5'-monophosphat als Substrat und völliger Mechanisierung mit einem Transfer-Analyser (Kem-O-Mat)

Zusammenfassung: Die kontinuierliche Methode zur spektrophotometrischen Bestimmung der 5'-Nucleotidase nach Heinz et al. ((1980) J. Clin. Chem. Clin. Biochem. 18, 781-788) wurde modifiziert und mit Inosin5'-monophosphat als Substrat am Kem-O-Mat Transfer-Analyser voll mechanisiert. Die an das Zwischenprodukt Wasserstoffperoxid gekoppelte Reduktion von NADP wurde für 10 min bei $340 \mathrm{~nm}$ und $30^{\circ} \mathrm{C}$ verfolgt. Verșchiedene Einflußgrößen auf die enzymatische Reaktion wurden untersucht, eingeschlossen Substratkonzentration, Reaktionsgeschwindigkeit, Linearität und Substratkonservierung. Werte bei Gesunden lagen im Bereich von 1-13 U/. Die Reproduzierbarkeit von Tag zu Tag wurde mit zwei verschiedenen käuflichen Kontrollseren ermittelt. Der Variationskoeffizient betrug $5 \%$ für $23 \mathrm{U} / \mathrm{l}$. Es bestand eine gute Ubereinstimmung zwischen den mit der vorgeschlagenen und einer teilmechanisierten kolorimetrischen Methode ermittelten Werten $(n=100, r=0,974, y=0,85 x-1,5)$. Abgesehen von der zeitaufwendigen Reagenzbereitung erlaubt die Methode die Bestimmung von 50 Proben je Stunde. Das Auftreten hoher Leerwerte im Serum bei bestimmten pathologischen Zuständen wird diskutiert.

J. Clin. Chem. Clin. Biochem. / Vol. 21, 1983 / No. 8 


\section{Introduction}

$5^{\prime}$-Nucleotidase (EC 3.1.3.5) is used as a biological marker in hepatobiliary disturbances; an increase in its catalytic activity in the serum is usually accompanied by a concomitant rise in serum alkaline phosphatase. In hyperphosphatasaemia, the hepatic specificity of 5'-nucleotidase enables it to be used to distinguish between the different etiologies of this condition, which may be hepatic, osseous, placental or intestinal.

Many methods of measuring its activity have been suggested. The oldest use adenosine 5'-monophosphate, a physiological substrate of 5 -nucleotidase. In this reaction

$$
\text { Adenosine } 5^{\prime} \text {-monophosphate }+\mathrm{H}_{2} \mathrm{O} \underset{\substack{\text { alkaline phosphatase } \\ \text { al-nucleotidase }}}{\longrightarrow}
$$

Adenosine + Inorganic phosphorus.

The methods sugggested differ, depending on how the reaction product is evaluated. Campbell (1) determined the inorganic phosphorus according to FiskeSubarow, and Hill \& Sammons (2) adapted the latter authors' procedure to a Technicon Autoanalyzer I. Since these methods proved insufficiently sensitive, various other authors $(3,4)$ proposed measuring the adenosine formed in the presence of adenosine deaminase (EC 3.5.4.17), the reaction being as follows:

Adenosine $\underset{\text { deaminase }}{\stackrel{\text { adenosie }}{\longrightarrow}}$ Inosine $+\mathrm{NH}_{3}$

Kalckar (5) measured the amount of adenosine which had disappeared at $265 \mathrm{~nm}$; whereas Persijn et. al. (6) and Belfield et al. (7) estimated the quantity of ammonia formed by Berthelot's colorimetric phenol hypochlorite reaction. More recently, Ellis et al. (8) and Bootsma et al. (9) suggested measuring the ammonia continuously by the action of a glutamate dehydrogenase, a procedure which the same authors adapted to the LKB 8600 device (10).

To avoid the drawbacks involved in endogenous ammonia generation (4), inosine $5^{\prime}$-monophosphate has been used as substrate. The inosine thus formed is degraded into hypoxanthine and then into uric acid, according to the following reaction scheme:

Inosine $5^{\prime}$-monophosphate $+\mathrm{H}_{2} \mathrm{O} \frac{5^{\prime} \text {-nucleotidase }}{\begin{array}{c}\text { or } \\ \text { on specific } \\ \text { phosphatases }\end{array}}$

Inosine + Inorganic phosphate

Inosine + inorganic phosphorus $\frac{\text { nucleoside }}{\text { phosphorylase }}$

Hypoxanthine + Ribose-1-P
Hypoxanthine $+2 \mathrm{H}_{2} \mathrm{O}+2 \mathrm{O}_{2} \underset{\text { xanthine oxidase }}{\longrightarrow}$

Uric acid $+2 \mathrm{H}_{2} \mathrm{O}_{2}$.

Dooley \& Racich (11) evaluated the uric acid formed at $293 \mathrm{~nm}$ directly, a technique adaptable to the Centrifichem system. Heinz et al. (12) measured the hydrogen peroxide formed using the catalase/aldehyde dehydrogenase system, giving the following reactions:

$2 \mathrm{H}_{2} \mathrm{O}_{2}+2$ Ethanol $\stackrel{\text { catalase }}{\longrightarrow} 2$ Acetaldehyde $+4 \mathrm{H}_{2} \mathrm{O}$

2 Acetaldehyde $+\mathrm{NADP}^{+}+2 \dot{\mathrm{H}}_{2} \mathrm{O} \frac{\text { aldehyde }}{\text { dehydrogeñase }}$

2 Acetic acid $+2 \mathrm{NADPH}+2 \mathrm{H}^{+}$.

All the authors quoted endeavoured to solve the problem of the specificity of adenosine 5 '-monophosphate and inosine 5'-monophosphate hydrolysis. Campbell (1) used differential 5' -nucleotidase inhibition by nickel salts. Another possibility is the use of the "enzyme diversion" technique involving highly concentrated diversion substrates preferentially hydrolysed by non-specific phosphatases; for this purpose Belfield et al. (7) used $\beta$-glycerophosphate at a concentration 50 times higher than that of the adenosine $5^{\prime}$-monophosphate, without any inhibitory effect on the 5'-nucleotidase. Persijn et al. (3) advocated the use of phenyl phosphate, for which non-specific phosphatases have a higher affinity than for $\beta$-glycerophosphate. The concentrations of the latter used by Dooley \& Racich'(11) \& Heinz et al. (12) were respectively 25 and 100 times higher than those of the inosine 5'-monophosphate.

The purpose of the present work was to adapt the continuous technique of Heinz et al. (12) to a transfer analyzer. Owing to the technical specifications of this device, we had to modify the method and the different parameters of the enzyme reaction. Automation was carried out at $340 \mathrm{~nm}$ and $30^{\circ} \mathrm{C}$ on. a Coultronics Kem-O-Mat transfer apparatus connected to a Tektronix 31 calculator.

\section{Materials and Methods}

Reagents

Stock solutions

Buffer I: $0.1 \mathrm{~mol} / \mathrm{l}$ triethañolamine (Boehringer Mannheim) $\overline{\mathrm{p}} \mathrm{H}$ 7.5, containing $0.1 \mathrm{~mol} / 1 \mathrm{KCl}$ and $1 \mathrm{mmol} / \mathrm{LDTA}$

Buffer II: $0.1 \mathrm{~mol} / \mathrm{l}$ triethanolamine (Boehringer Mannheim) $\mathrm{pH}$ 7.5, containing $0.1 \mathrm{~mol} / 1 \mathrm{KCl}$

$0.1 \mathrm{~mol} / \mathrm{K} \mathrm{KCl}$ (Merck) 


\section{$1 \mathrm{~mol} / / \mathrm{KH}_{2} \mathrm{PO}_{4}$ (Prolabo)}

$1 \mathrm{~mol} / 1 \mathrm{MgCl} 2 \times 6 \mathrm{H}_{2} \mathrm{O}$ (Merck)

$0.01 \mathrm{~mol} / \mathrm{h}$ inosine 5 '-monophosphate (Boehringer Mannheim 106704): $5 \mathrm{mg}$ are dissolved in $1 \mathrm{ml}$ triethanolamine buffer II

Absolute ethanol (Merck); D $=0.789 \mathrm{~kg} / \mathrm{l} ; M_{\mathrm{r}}=46.07$

NADP $^{+}$(Boehringer Mannheim 128040) $M_{\mathrm{r}}=787.4$

Sodium $\beta$-glycerophosphate (Merck 4168); $M_{\mathrm{r}}=306.12$

$7 \mathrm{U} / \mathrm{mg}$ aldehyde dehydrogenase (EC 1.2.1.5) (Sigma A 6758)

$20 \mathrm{~g} / \mathrm{l}$ (about $65000 \mathrm{U} / \mathrm{mg}$ ) catalase (EC 1.11.1.6) (Boehringer Mannheim 106810)

$5 \mathrm{~g} / \mathrm{l}$ (about $20 \mathrm{U} / \mathrm{mg}$ ) nucleoside phosphorylase (EC 2.4.2.1) (Boehringer Mannheim 107964)

$10 \mathrm{~g} / \mathrm{h}$ (about $0.4 \mathrm{U} / \mathrm{mg}$ ) xanthine oxidase (EC 1.2.3.2) (Boehringer Mannheim 110422)

The xanthine oxidase suspension was dialysed overnight at $+4^{\circ} \mathrm{C}$ against $0.1 \mathrm{~mol} / \mathrm{KCl}$. At $+4^{\circ} \mathrm{C}$, the dialysed enzyme was stable for one week.

\section{Reaction buffer}

$6 \mathrm{ml}$ of triethanolamine buffer I was combined with $12 \mathrm{ml}$ bidistilled water and nine other agents were added in the order in which they are specified below: $0.66 \mathrm{ml}$ ethanol, $6.6 \mu \mathrm{l}$ catalase, $3.5 \mathrm{mg} \mathrm{NADP}{ }^{+}, 170 \mathrm{mg}$ sodium $\beta$-glycerophosphate, $13.5 \mu \mathrm{l}$ $\mathrm{KH}_{2} \mathrm{PO}_{4}, 0.1 \mathrm{ml} \mathrm{MgCl}, 4.5 \mathrm{mg}$ aldehyde dehydrogenase, $93 \mu \mathrm{l}$ nucleoside phosphorylase and $0.66 \mathrm{ml}$ xanthine oxidase.

This reaction mixture, prepared as required, remained stable for 4 hours at $+4^{\circ} \mathrm{C}$

\section{Concentration of constituents}

The concentrations of the constituents of the reaction buffer are given in table 1 , and the composition of the reaction medium is indicated in table 2.

\section{Control sera}

Decision serum (Beckman Level 3, Cat. 660410).

5'ND (Control E, Sigma, Cat. N 1009).

\section{Methodology}

Principle

For analysis, serum was diluted $1 / 10$ in reaction buffer and the mixture was preincubated at $30^{\circ} \mathrm{C}$ for 15 minutes.

During preincubation, a slight increase in absorbance was observed; this constituted the reaction blank, which was automatically substracted from sample values.

The reaction was started by adding inosine 5'-monophosphate.

\section{Programming on Kem-O-Mat transfer apparatus}

The soft routine parameters were the following:

$\begin{array}{lc}\text { Reaction buffer } & 450 \mu \mathrm{l} \\ \text { Sample } & 49.5 \mu \mathrm{J} \\ \text { Substrate added at revolution No. } 15 & 20 \mu \mathrm{l} \\ \text { First reading at revolution No. } & 15 \quad \text { (l revolution = 64s) } \\ \text { Second reading at revolution No. } & 25 \mathrm{U} / \\ \text { Linearity limit } & 100 \mathrm{U} / \\ \text { Calibration coefficient } & 168.6 \\ \text { Temperature } & 30^{\circ} \mathrm{C} \\ \text { Filter } & 340 \mathrm{~nm}\end{array}$

\section{Calculation of the results}

The Tektronix calculator used gave the $U / 1$ value directly after deduction of the reaction blank, which constituted a control for the validity of the reagents.

One unit of 5'-nucleotidase was defined as the amount of enzyme which transformed $1 \mu \mathrm{mol}$ of inosine $5^{\prime}$-monophosphate in one minute at $30^{\circ} \mathrm{C}$.

\section{Results}

Activity of xanthine oxidase after dialysis

After dialysis, xanthine oxidase activity was measured using $\left[8-{ }^{14} \mathrm{C}\right]$ hypoxanthine as substrate (13), giving the reactions:

Tab. 1. Composition and concentration of components in reaction buffer.

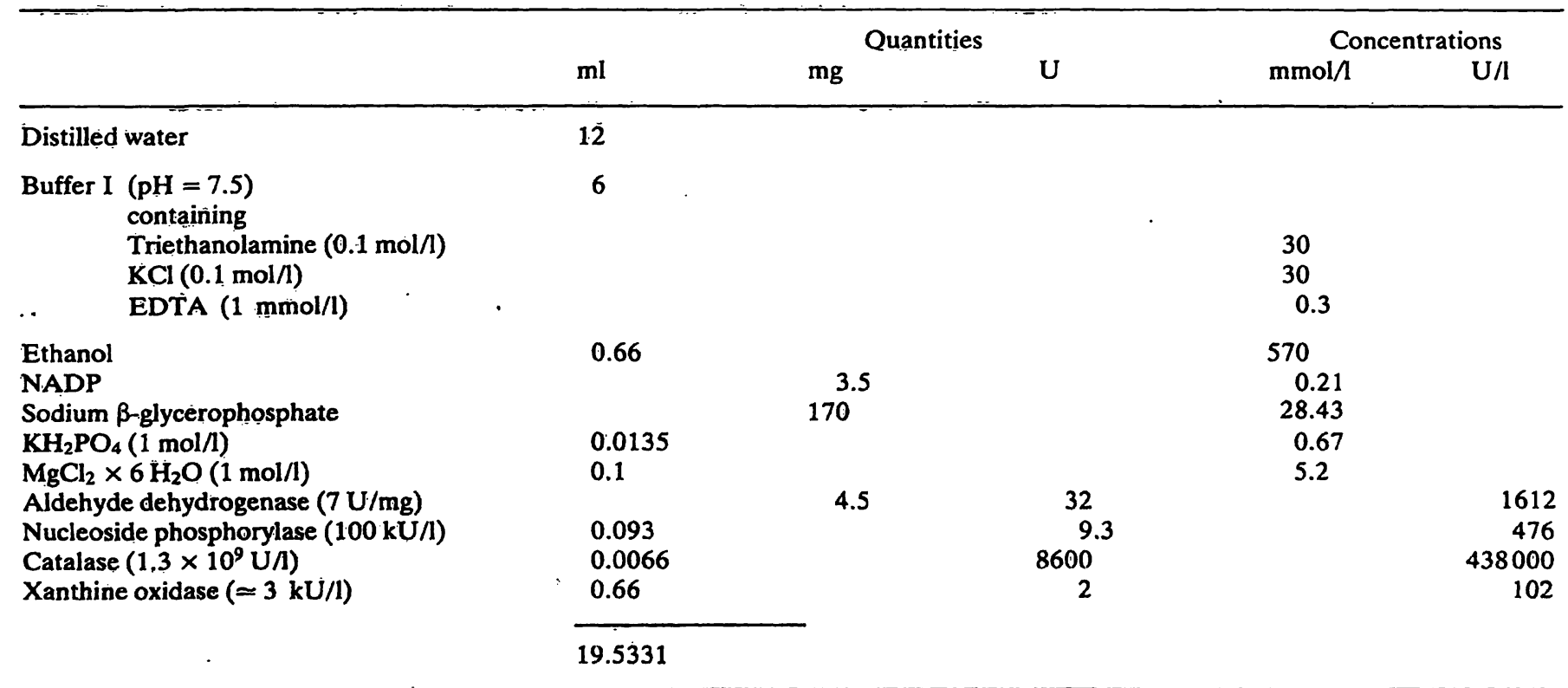


$\left[8-{ }^{14} \mathrm{C}\right]$ hypoxanthine $\underset{\text { oxidasc }}{\stackrel{\text { anthine }}{\longrightarrow}}\left[8-{ }^{14} \mathrm{C}\right]$ xanthine

$\left[8-{ }^{14} \mathrm{C}\right] x$ anthine $\underset{\text { oxidase }}{\stackrel{\text { xanthine }}{\longrightarrow}}\left[8-{ }^{14} \mathrm{C}\right]$ uric acid.

Oxidation products were separated by thin layer chromatography on MN polygram cellulose and located by autoradiography. The ratio of the radioactivity of (hypoxanthine + xanthine + uric acid) spots was used to calculate xanthine oxidase activity. The amount of xanthine oxidase was expressed in $U / 1$.

The xanthine oxidase activities measured in three samples were respectively $2.8 \mathrm{U} / \mathrm{h}, 2.99 \mathrm{U} / \mathrm{h}$ and 3.6 $\mathrm{U} /$; the level of activity found after dialysis was therefore fairly constant.

\section{5'-IMP concentrations}

5 '-Nucleotidase was measured with increasing inosine 5'-monophosphate concentrations ranging from 19 to $385 \mu \mathrm{mol} / 1$.

The Lineweaver-Burk plot of $1 /[\mathrm{S}]$ versus $1 / \mathrm{v}$, expressed as $\mathrm{U} /$, was a straight line and allowed calculation of an apparent $K_{\mathrm{m}}$ value of $12 \mu \mathrm{mol} / 1$ (fig. 1).

Inhibition of inosine $5^{\prime}$-monophosphate hydrolysis

Our purpose was to study the first analytical step of the rection scheme described by Heinz et al. (12).

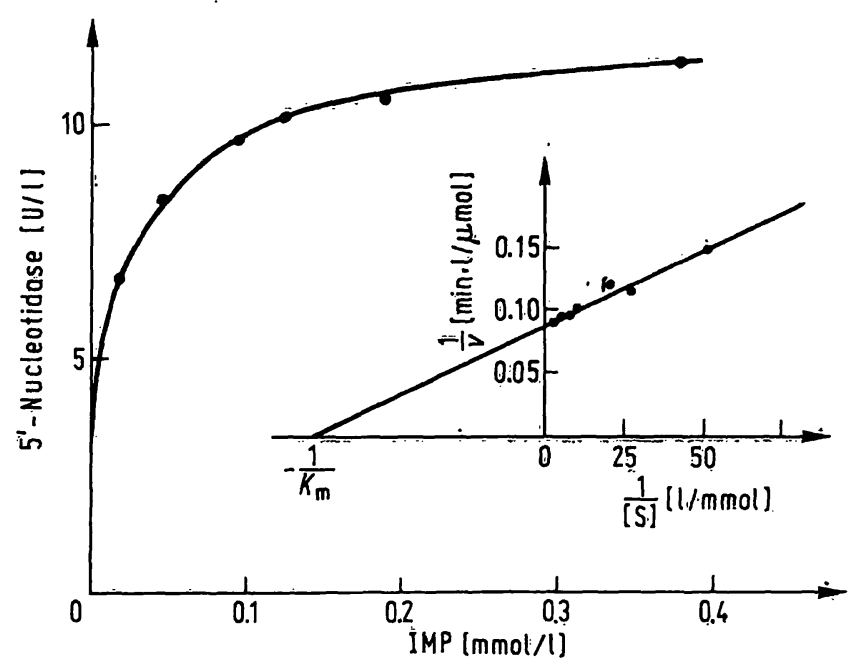

Fig. 1. Effect of increasing inosine 5 -monophosphate concentrations. The assay system was tested with increasing concentrations of inosine $5^{\prime}$-monophosphate from 19 to 385 $\mu \mathrm{mol} / \mathrm{l}$.

Inset: double reciprocal plot of 5 -nucleotidase activity versus inosine 5 '-monophosphate concentrations.

\section{Principle}

$\left[8-{ }^{14} \mathrm{C}\right]$ Inosine $5^{\prime}$-monophosphate is chosen as substrate; it is hydrolysed by $5^{\prime}$-nucleotidase and nonspecific alkaline phosphatases to yield $[8-14 \mathrm{C}]$ inosine and inorganic phosphate. Glycerol 2-phosphate acts as "diversion substrate", it is preferentially hydrolysed by non-specific alkaline phosphatases.

Tab. 2. Composition and concentration of components in reaction mixture.

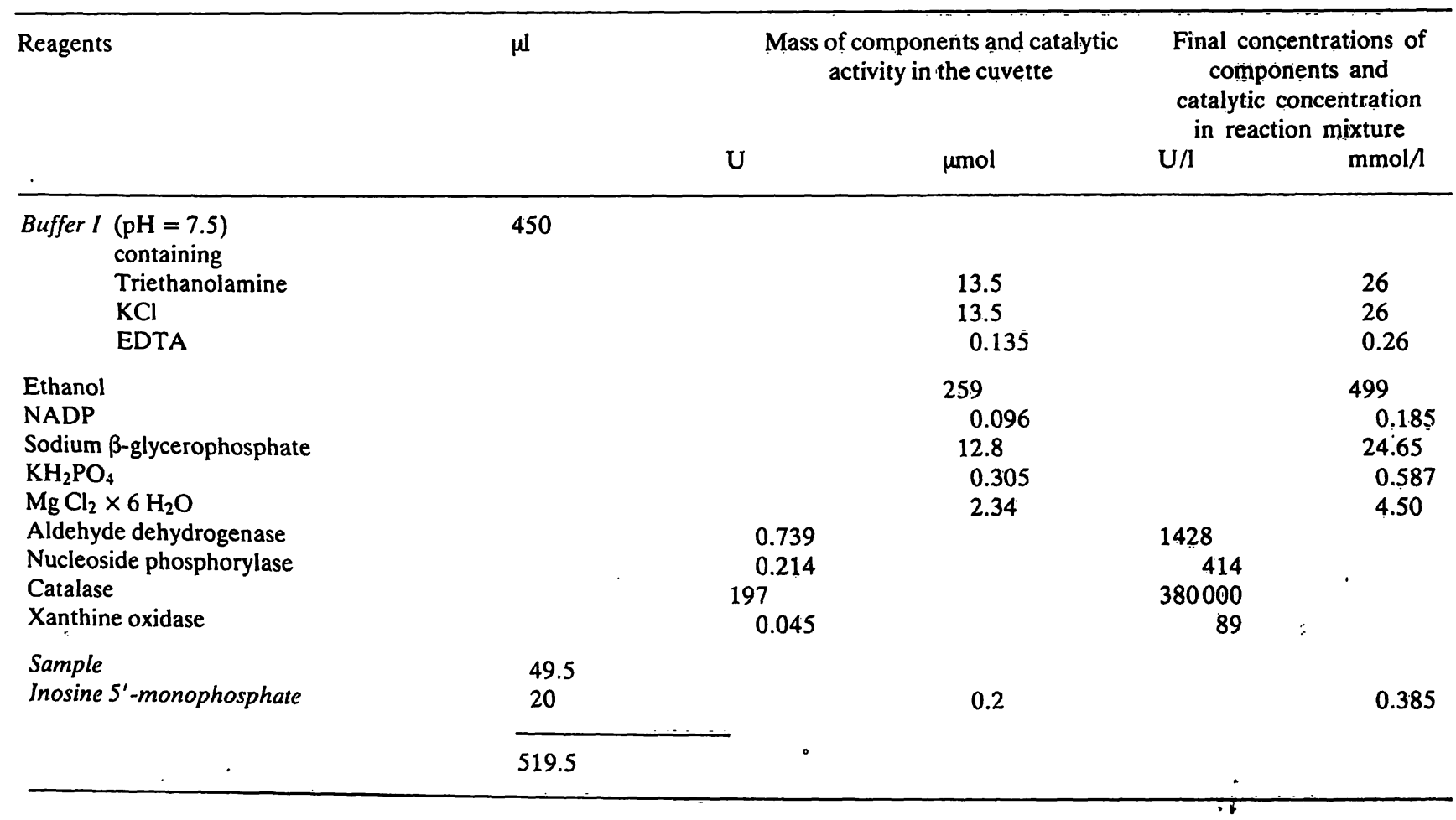




\section{Assay}

A working substrate solution is prepared as follows: $330 \mu \mathrm{mol} /\left[8-{ }^{14} \mathrm{C}\right]$ inosine $5^{\prime}$-monophosphate (specific activity: $111 \mathrm{MBq} / \mathrm{mmol}=3 \mathrm{mCi} / \mathrm{mmol}$ ) is dissolved in a $0.1 \mathrm{~mol} / 1$ triethanolamine buffer $\mathrm{pH} 7.5$ : the reaction mixture contains also $6 \mathrm{mmol} / \mathrm{l}$ magnesium chloride and $28 \mathrm{mmol} / \mathrm{l}$ glycerol 2-phosphate. After 15 minutes incubation at $30^{\circ} \mathrm{C}$, the reaction is stopped with $150 \mathrm{~g} / \mathrm{kg}$ perchloric acid. Nucleotide and nucleoside are separated by paper chromatography; the chromatogram is cut and radioactivity is measured with a liquid scintillation counter.

\section{5'-Nucleotidase inhibition}

$\alpha_{1} \beta$-Methylene adenosine 5 '-diphosphate has been recently described as a specific inhibitor of the $5^{\prime}$ nucleotidase activity (15). Enzyme activity was determined with increasing amounts of the inhibitor; maximal 5'-nucleotidase inhibition is achieved for an inhibitor concentration higher than $250 \mu \mathrm{mol} / 1$ (fig. 2 ). Simultaneous use of $\alpha_{1} \beta$-methylene adenosine 5 '-diphosphate and glycerol 2-phosphate achieves a nearly total inhibition of inosine 5'-monophosphate hydrolysis. According to this assay it can be concluded that glycerol 2-phosphate does act as a powerful "diversion substrate" for non-specific alkaline phosphatases.

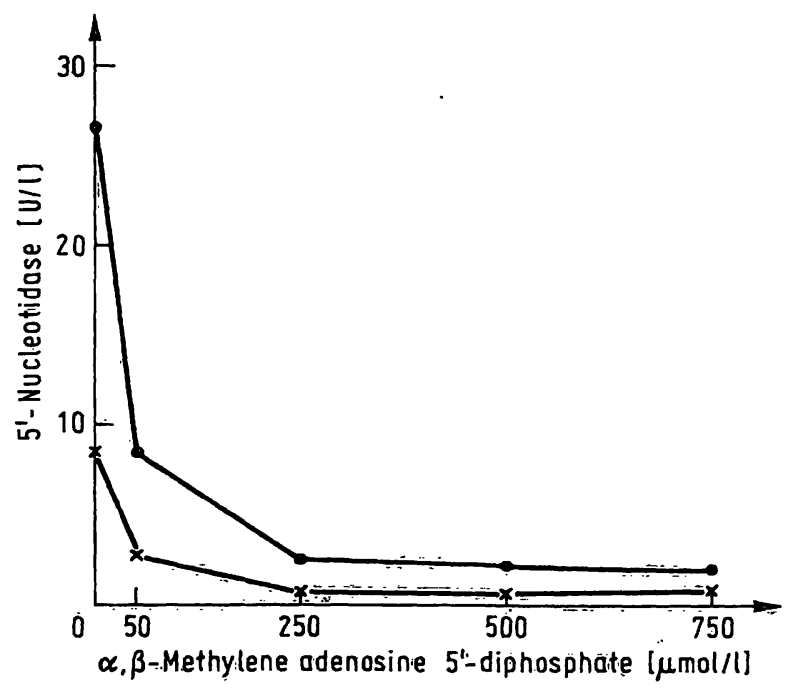

Fig. 2. Specific inhibition of 5'-nucleotidase catalytic activity by $\alpha_{1} \beta$-methylene adenosine 5 '-diphosphate

$x-x-x-$ Serum with normal 5'-nucleotidase catalytic concentration $(8.4 \mathrm{U} / \mathrm{l})$

- - - Serum with high 5'-nucleotidase catalytic concentration $(26.4 \mathrm{U} / \mathrm{l})$.

\section{Optimal concentration of glycerol 2-phosphate}

5'-Nucleotidase activity was measured with increasing amounts of glycerol 2-phosphate (fig. 3): gradual diminution of the measured catalytic activity is due

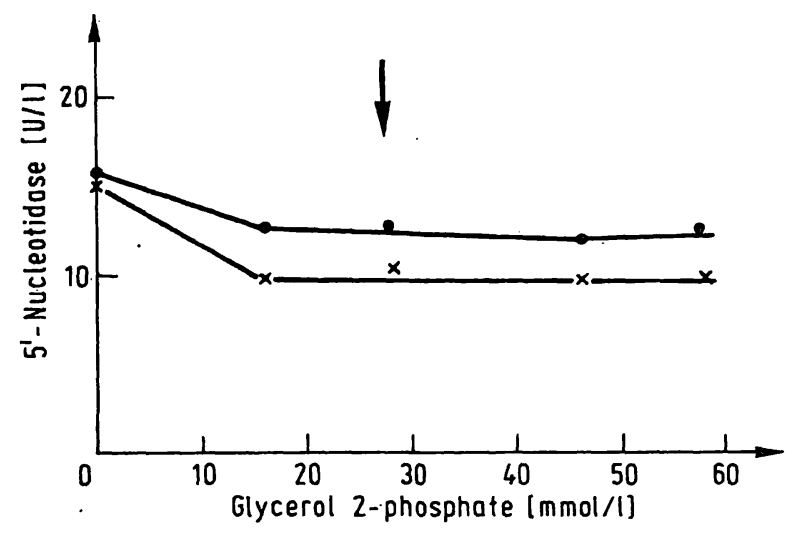

Fig. 3. Choice of an optimal glycerol 2-phosphate concentration; 5 -nucleotidase catalytic activity was measured in two sera by adding increasing amounts of "diversion substrate".

to the progressive effect of the "diversion substrate". In order to achieve a maximal inhibition of non-specific alkaline phosphatases a $28 \mathrm{mmol} / /$ concentration was chosen (see tab. 2).

\section{Technical performances}

\section{Kinetics}

a) Preincubation phase

Reaction and serum blank absorbance (A) was observed for 20 minutes; for the reaction blank, $\overline{\Delta A}$ was minimal and for the serum blank it was of the order of 0.012 for normal catalytic activity. This value was automatically deducted from the $(\Delta \mathrm{A})$ recorded during the reaction. The serum blank absorbance was stable by the 10 th minute (fig. 4). For pathological activity (55 U/1), the serum blank was observed to be high $(\Delta \mathrm{A}=0.55$; fig. 4$)$.

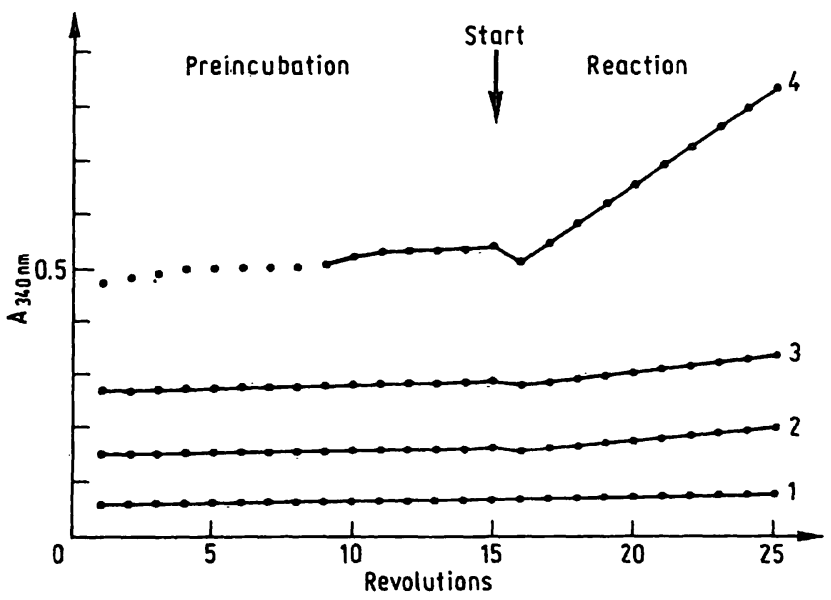

Fig. 4. Kinetic study

Kinetics during the incubation phase and enzyme reaction:

Curve (1): $\quad$ reaction blank

Curve (2) and (3): two serum samples with normal catalytic concentrations, respectively 4.2 and $9.1 \mathrm{U} / \mathrm{I}$

Curve (4): $\quad$ serum with pathological activity (55 U/I) 


\section{b) Reaction kinetics}

Absorbance was first read 12 seconds after adding inosine 5 '-monophosphate and variations in absorbance were measured for ten minutes thereafter (fig. 4).

The mean $(\Delta \mathrm{A})$ values obtained for sera with normal catalytic activity over a 10 minute period ranged from 0.030 to 0.080 . Although low, these values were sufficiently reliable, in view of the optical performances of the equipment used.

In addition, reaction kinetics were studied over a period of 60 minutes (fig. 5). Up to 30 minutes, the reaction was linear.

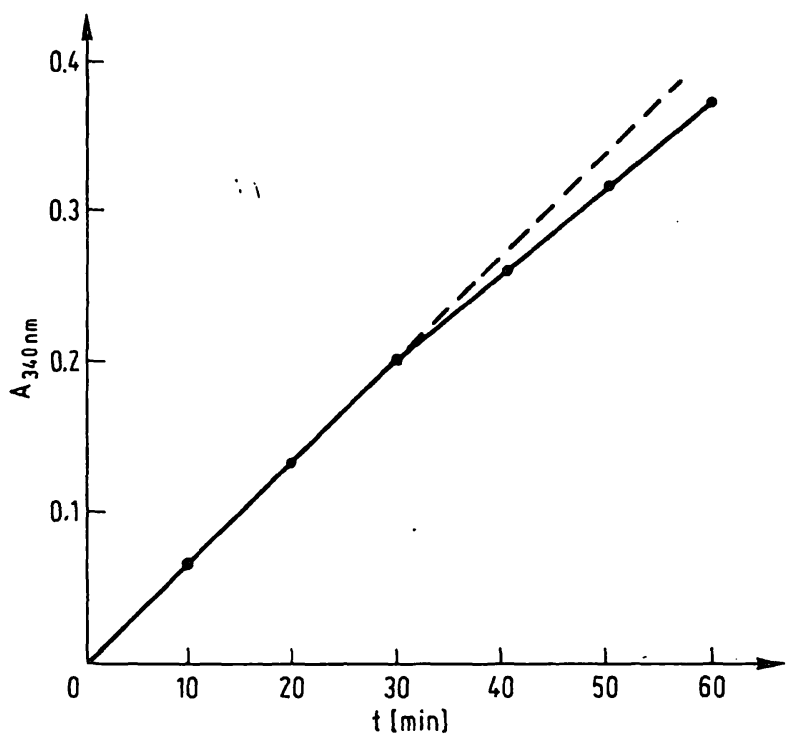

Fig. 5. Study of enzyme reaction kinetics for 60 minutes.

The reading time finally chosen (10 minutes 40 seconds $=10$ revolutions) was within the linearity zone and made it possible to combine an acceptable degree of variation in absorbance with the specific requirements of the Kem-O-Mat equipment (maximum number of revolutions: 25 ).

\section{Effects of 5'-nucleotidase activity}

Enzyme catalytic activity was measured in 6 and 9 dilutions of two serum samples with high 5 '-nucleotidase activity (95 $\mathrm{U} / \mathrm{l}$ and $110 \mathrm{U} / \mathrm{l}$ respectively). Each dilution was made in duplicate. Enzyme kinetics were directly proportional to the catalytic concentration of the enzyme in the reaction medium (fig. 6).

In the soft routine programmed, the linearity limit was fixed at $10 \mathrm{U} / \mathrm{l}\left(\Delta \mathrm{A}=0.06 \mathrm{~min}^{-1}\right)$.

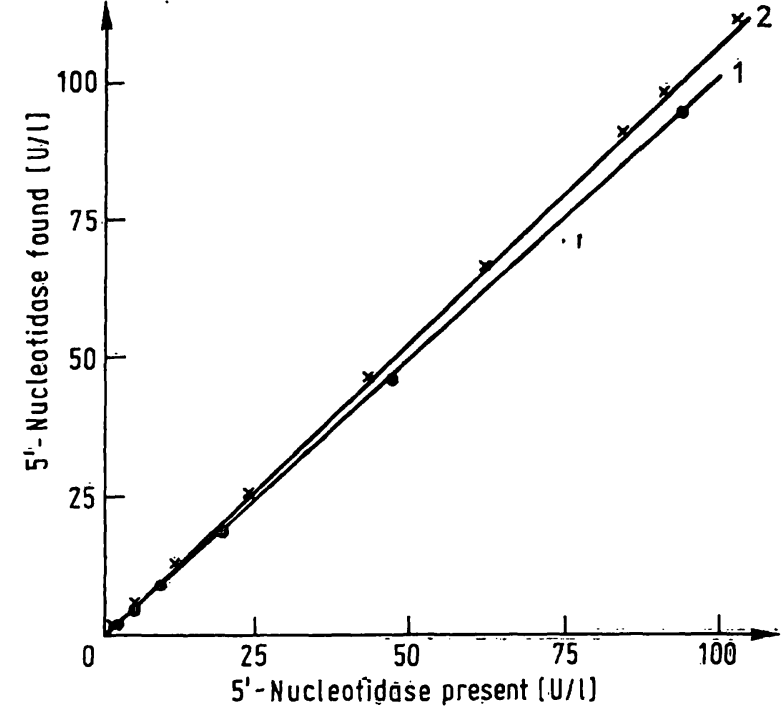

Fig. 6. Effect of the enzyme catalytic activity concentration. Study of two serum samples with high catalytic activity concentrations:

serum 1: $95 \mathrm{U} / 1$

serum 2: $110 \mathrm{U} / \mathrm{l}$.

\section{Recovery test}

A serum control with a known $5^{\prime}$-nuclèotidase catalytic activity was added to two native human sera whose $5^{\prime}$-nucleotidase activity lay in the "normal" range

Serum No. 1: Measured catalytic concentration $21.3 \mathrm{U} / \mathrm{l}$ expected catalytic concentration $22.0 \mathrm{U} / \mathrm{l}$ recovery. $\quad 96.8 \%$

Serum No. 2: Measured catalytic concentration $\quad 41.3 \mathrm{U} / \mathrm{l}$ expected catalytic concentration $\quad 44.0 \mathrm{U} / \mathrm{l}$ recovery $\quad 93.8 \%$

\section{Precision of the method}

a) Repeatability

Three serum samples with increasing levels of catalytic activity were analysed ten times each during the same series of experiments (tab. 3).

For normal physiological catalytic activity, the intraseries coefficient of variation was close to $5 \%$, and for high catalytic activity, it was $1 \%$.

Tab. 3. Within-run precision of the determination of $5^{\prime}$-nucleotidase catalytic activity concentration $(n=10)$.

\begin{tabular}{lll}
\hline $\begin{array}{l}\text { Mean } \\
\text { U/I }\end{array}$ & $\begin{array}{l}\text { Standard deviation } \\
\text { U/I }\end{array}$ & $\begin{array}{l}\text { Coefficient of variation } \\
\%\end{array}$ \\
\hline 3.9 & 0.19 & 4.89 \\
23.6 & 0.19 & 0.81 \\
88 & 0.99 & 1,14 \\
\hline
\end{tabular}




\section{b) Reproducibility}

Between-day reproducibility was estimated with Beckman's Decision Level 3 control serum, whose $5^{\prime}$-nucleotidase catalytic concentration is normal $(\bar{x}=5.98 \mathrm{U} / \mathrm{l})$ and with Sigma control serum which has high catalytic concentration $(\bar{x}=22.6 \mathrm{U} / \mathrm{l})$.

Enzymatic activity was measured daily for 15 days. For normal and high catalytic activities, the coefficients of variation were 14.5 and $5 \%$ respectively.

\section{Preservation}

a) Enzyme stability

Ten samples of fresh serum were analyzed on the day of sampling and then frozen at $-20^{\circ} \mathrm{C}$. Further tests 15 days later showed satisfactory enzyme preservation.

\section{b) Stability of the substrate}

The preservation of the inosine 5 '-monophosphate solution was tested at $+4{ }^{\circ} \mathrm{C}$ on the following:

two serum samples with normal catalytic concentration (2.36 U/l and $12.31 \mathrm{U} / \mathrm{l}$ respectively); 5'-nucleotidase activity was measured in solutions of substrate prepared on days $0,3,9$ and 15 . No noteworthy variation in this activity was observed.

three serum samples with high catalytic concentration $(28,36$ and $51 \mathrm{U} / 1$ respectively); 5'-nucleotidase activity was measured with substrate solutions prepared on days 0 and 45 . Under these conditions, considerable enzyme activity was lost from all three samples $(60,70$ and $80 \%$ respectively).

\section{Correlations}

A hundred serum samples were measured by the method described and the results compared with those obtained by the automated continuous flow technique using an AAI Autoanalyzer (16) (fig. 7).

The correlation was excellent, since the coefficient of correlation was 0.974 . The regression line is defined by the formula $y=0.85 x-1.5$.

The means obtained were $11.8 \mathrm{U} / \mathrm{l}$ for the technique described and 15.6 for the one used for comparison.

Partial correlations were studied on 29 pathological serum samples (alkaline phosphatase $>100 \mathrm{U} / \mathrm{l}$; $5^{\prime}$ nucleotidase $>18 \mathrm{U} / \mathrm{l}$ ) by the continuous flow technique; again the correlation was excellent $(r=0.974)$. The regression line formula calculated was $y=0.94 x-6.9$.

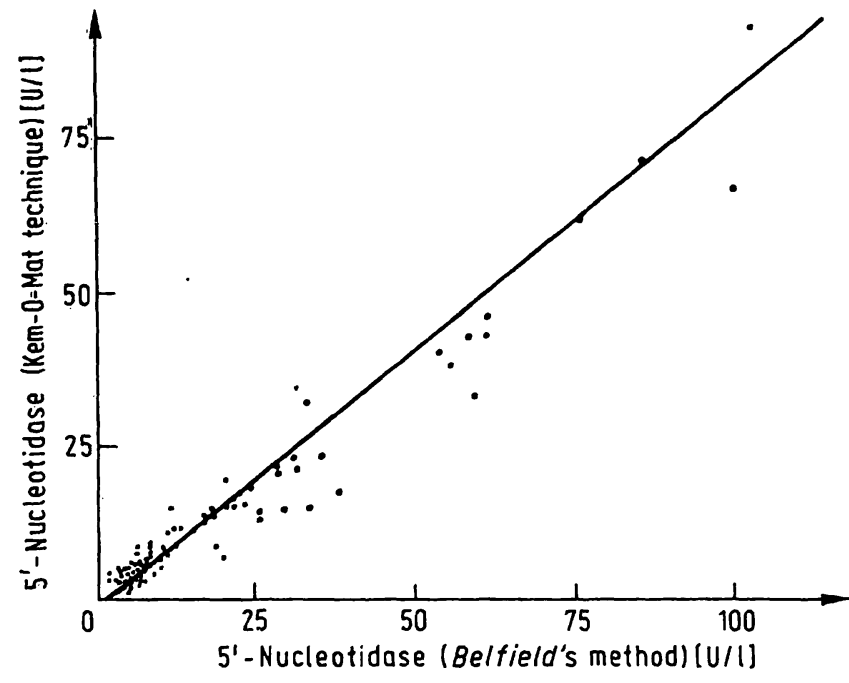

Fig. 7. Correlation study. Comparison of the results for the automated technique described (y) with those for Belfield's colorimetric method $(x)$.

\section{Normal values}

Correlations were studied on 69 serum samples from adult subjects. The samples displayed normal alkaline phosphatase catalytic concentration (below 17 $U / 1$ with the continuous flow technique). Mean values for the two methods were:

4.7 U/1 for the method described, and $6.4 \mathrm{U} / 1$ for the continuous flow method.

The highest extreme value for the method described was $10.9 \mathrm{U} / \mathrm{l}$.

A complementary study made of 14 serum samples in which 5 -nucleotidase activity reached the upper limit of the usual values given by the continuous flow method (between 15 and $20 \mathrm{U} / \mathrm{l}$ ); for the method described here, the mean value found was $12.8 \mathrm{U} / \mathrm{l}$.

Consequently, we fixed the upper limit for normal values at $13 \mathrm{U} / \mathrm{l}$.

\section{Discussion}

The principle used here for measuring serum $5^{\prime}$-nucleotidase catalytic activity was originally proposed by Dooley \& Racich and Heinz et al. (12) and reproduces in vitro the scheme of purine nucleotide degradation in vivo, up to the uric acid stage, the final step of purine catabolism in man. Measurement of the products of hypoxanthine oxidation by xanthine oxidase (i.e. uric acid or $\mathrm{H}_{2} \mathrm{O}_{2}$ ) permitted calculation of 5 '-nucleotidase catalytic activity.

The degradation of inosine 5 '-monophosphate to uric acid was direct and complete, in contrast to that of adenosine $5^{\prime}$-monophosphate (a substrate whose 
use has been suggested by many authors); most of the adenosine formed by adenosine 5'-monophosphate hydrolysis was deaminated by an indirect route leading to inosine and thence to hypoxanthine formation; in addition, adenosine degradation to adenine by the nucleoside phosphorylase system seems very restricted in man (17).

Of the two procedures involving the use inosine $5^{\prime}-$ monophosphate $(11-12)$, we thought it preferable to choose that of Heinz et al. (12), which measures the $\mathrm{H}_{2} \mathrm{O}_{2}$ formed, a product which, unlike uric acid, is not initially present in the serum.

At the same time, it is not impossible that in hyperuricaemic subjects treated with allopurinol (a powerful xanthine oxidase inhibitor) the reaction which oxidizes hypoxanthine to uric acid might be inhibited. However, although the serum allopurinol concentrations recorded in hyperuricaemic subjects are sufficient to inhibit liver xanthine oxidase, they might not suffice to inhibit the xanthine oxidase activity introduced into the reaction medium, an activity about a hundred times that in human liver (13).

Human liver xanthine oxidase was inhibited by uric acid $(1.6 \mathrm{mmol} / \mathrm{l})$ when xanthine oxidase was the substrate (18). In view of the relatively high $K_{\mathrm{i}}$ for uric acid $(1.6 \mathrm{mmol} / \mathrm{l})$, the biological role of uricaemia is not obvious: in very severe hyperuricaemias, the serum uric acid concentration is far lower than the $K_{\text {i }}$.

Adaptation to a Kem-O-Mat transfer analyzer of the principle of measurement suggested by Heinz et al. (12) enabled us to redefine some of the method's parameters.

The inosine 5'-monophosphate concentration chosen for the reaction medium corresponded to 32 times the apparent $K_{\mathrm{m}}$ values of the 5'nucleotidase serum (12 $\mu \mathrm{mol}$; fig. 1$)$. This value was comparable to the one reported by Heinz et al. ( $30 \mu \mathrm{mol})$. Satu-. rating substrate concentrations do therefore accurately measure 5'-nucleotidase activity. This was verified by the fact that in serum samples with normal $(13 \mathrm{U} / \mathrm{l})$, the amount of inosine $\overline{5}^{\prime}$-monophosphate transformed in 10 minutes of reaction time did not exceed $3 \%$, and, for samples with the highest acceptable catalytic concentration (100 U/1), was never more than $25 \%$.

The reaction time chosen (10 minutes) was in the linearity zone. Substrate oxidation kinetics were constant, at least up to 30 minutes of incubation time (fig. 5).

The preincubation phase made it possible to record the variation in the absorbance of the buffer + se- rum mixture; this value of about $0.012 \mathrm{~A}$ probably corresponded to the oxidation of the oxypurines in the sample by xanthine oxidase. It is logical to assume that the serum oxypurine concentration contributes to the variation in serum blank absorbance.

In primary and secondary liver cancer cases, Ramsdell \& Kelly (19) reported hyperoxypurinaemia combined with hypouricaemia due to lack of xanthine oxidase synthesis by the liver. In the case reported in figure 4, which showed a large variation in serum blank absorbance $(A=0.55)$ and $5^{\prime}$-nucleotidase catalytic concentration of $55 \mathrm{U} / 1$, it is plausible to connect the high serum blank with the hyperoxypurinaemia associated with liver aetiology. In the very rare cases of xanthine-oxidase deficiency (essential xanthinuria), the large rise in blood oxypurine will pröbably be reflected by a greâtèr vạniáation in serum blank absorbance.

The precision of the method described here is very satisfactory compared to that of the procedures reported earlier. For an average enzyme catalytic cọncentration of $30 \mathrm{U} / \mathrm{l}$, the intraseries coefficients of variation were $8 \%$ for the colơrimètric techṇiquies (16) and 5\% for the enzymatic techniques according to Ellis et al. $(8,10)$. In our tests, the intraseries CV was $1 \%$.

Between-day precision was also excellent with the present method, compared to that obtained by $D o o-$ ley's kinetic method (11); this authors found a coefficient of variation of $14 \%$, where 5 -nucleotidase $=5 \overline{3} \dot{U} / l$, compared to our figure, which was close to $5 \%$ for 5 -nucleotidâase $=23 \mathrm{U} / \mathrm{l}$ :

The present linearity limit was fixed at $100 \mathrm{U} / \mathrm{l}$, i.e. at 8 times the threshold physiological catalytic activity concentration. this result is perfectly superimposable on those obtained by other methods.

In the course of our tests, we were unable to define the linearity of the reaction for enzyme catalytic concentrations above $110 \mathrm{U} / \mathrm{l}$.

The usual values, determined on 69 samples, ranged from 1 to $12 \mathrm{U} / \mathrm{l}(\overline{\mathrm{x}}=4.70 \mathrm{U} / \mathrm{l})$ and were distinctly higher than those reported by Heinz et al. (1.5 to 2.9 $\mathrm{U} /$ ). The latter values do not seem to us representative of a normal popülation, given the small number of samples analysed.

On the other hand, the mean of our usual values $(\bar{x} \doteq 4.70 \mathrm{U} / \mathrm{l})$ is very close to the one obtained by Belfield's method $(\overline{\mathrm{x}}=6.40 \mathrm{U} / \mathrm{)})$.

Six months of experimentation in our laboratory enabled us to appreciate the main qualities of the method proposed here: reliability a qu practicability. 


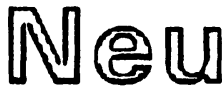 \\ \#neparin low doser Test}

Erstmals Kontrolle der "Thromboseprophylaxe" mit niedrig dosiertem Heparin möglich
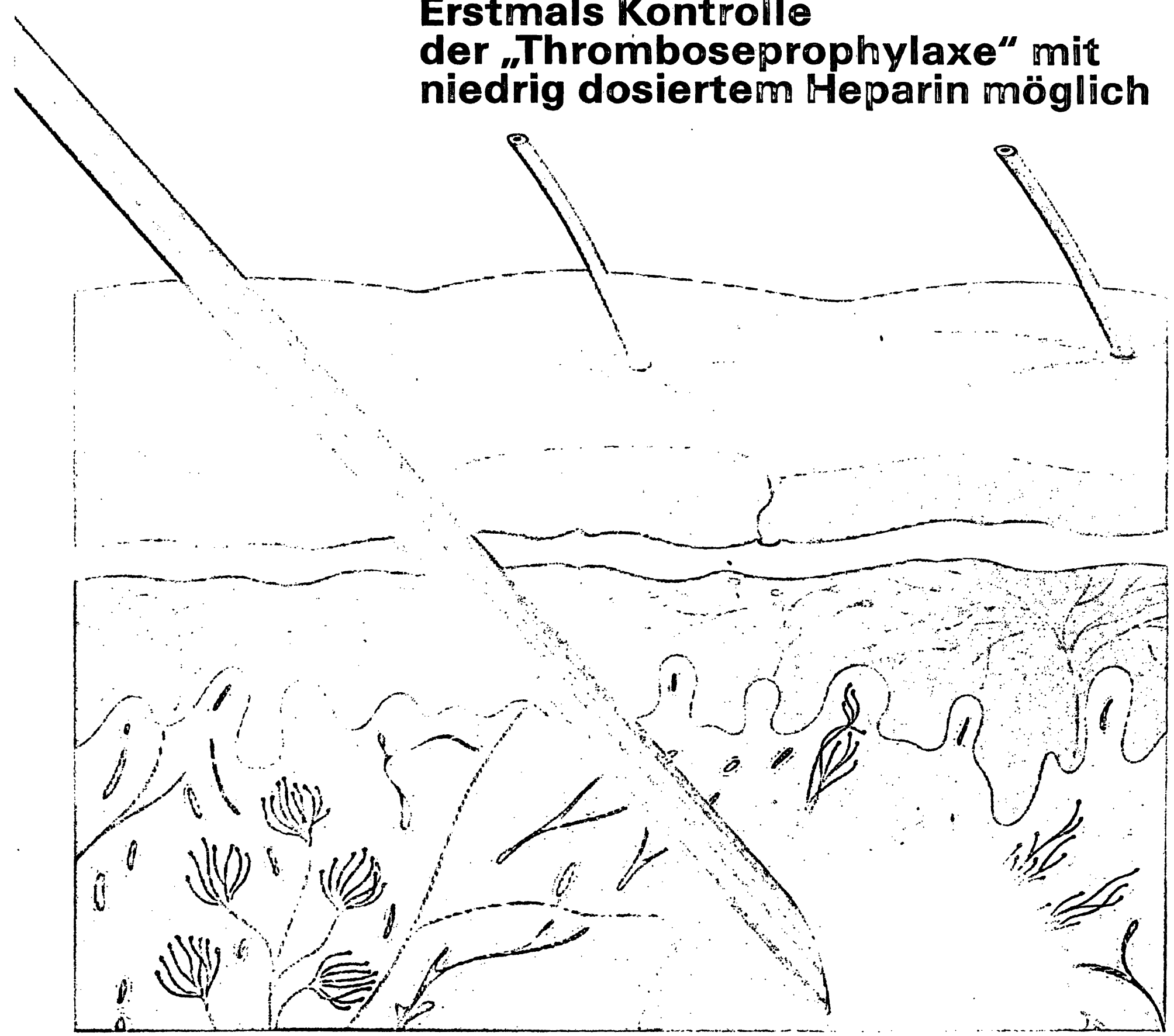

Subkutan appliziertes Heparin wird durch zahlreiche Faktoren beeinflußt. Von Patient zu Patient treten bei einer schematischen Dosierung unterschiedliche Wirkspiegel auf. In vielen Fällen wird deshalb kein ausreichender Schutż erreicht (non-responder).

Die Kontrolle des Heparinspiegels bei der low dose Prophylaxe schafft die Voraussetzung für eine individuelle Dosierung. Damit wird für den einzelnen Patienten ein verbesserter Thromboseschutz erreicht.

Der ıHeparin low doser Test erfaßt die antithrombotische Wirkung des subkutan applizierten Heparins in einem Konzentrationsbereich von 0,010.2 USP-Einheiten/ml Plasma. In diesem Bereich liegt der Heparinspiegel unter der low dose Prophylaxe. Mit den bisher üblichen konventionellen Testmethoden können diese niedrigen Konzentrationen nicht erfaßt werden.

\section{Coupon}

I Bitte senden Sie mir ausführliche Informationen über

I H Heparin low doser Test

I

Name

Straße

PLZZ/Or

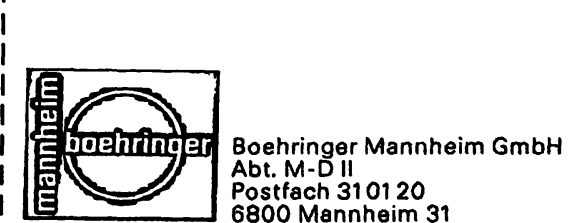




\section{Fibrinogen \\ Recent Biochemical and Medical Aspects}

\section{Proceedings $\cdot$ International Symposium \\ Max-Planck-Institute for Biochemistry \\ February 17-18, 1981, Martinsried/Munich, Germany .,}

Editors A. Henschen - H. Graeff - F. Lottspeich

$1982.17 \mathrm{~cm} \times 24 \mathrm{~cm} . X, 400$ pages. Numerous illustrations. Hardcover.

DM 135,-; approx. US $\$ 61.50$ ISBN 3110085437

This volume is a record of the contributions to the symposium entitled "Fibrinogen - Recent Biochemical and Medical Aspects." The object of this book is to review the progress in the biochemistry and pathobiochemistry of fibrinogen and to facilitate the exchange of ideas and experience between investigators from different fields.

Contents (Main chapters)

Physicochemical Aspects - Biochemical Aspects - Abnormal Fibrinogeñs - Fibrinopeptide Determination - Fibrinogen - Fibrin Complexes - Fibrin(ogen) Degradátion and Crosslinked Fibrin Derivatives - Biological Effects of Low Molecular Weight Peptides and Interaction with other Proteolysis . Author Index · Subject Index.

\section{Fibrinogen}

\section{Structure - Functional Aspects - Metabolism}

Proceedings - Workshop on Fibrinogen

May 12-14, 1982, Leiden, The Netherlands

Editors F. Haverkate - A. Henschen - W. Nieuwenhuizen - P.W. Straub

$1983.17 \mathrm{~cm} \times 24 \mathrm{~cm}$. XVI, 343 pages. Numerous illustrations.

Hardcover. DM 145,-; approx. US \$ 66.00 ISBN 3110089866

The scope of the conference was focused on research of fibrinogen and its derivatives and especially to its biochemical, physico-chemical and physiological aspects. The findings of the conference certainly will provide a firm basis for the development of new clinical applications.

Contents (Main chapters)

Physicochemical Aspects - Fibrinogen-Fibrin Conversion - Interaction with Divalent Cations · Abnormal Fibrinogens - Fibrinogen Derived Products in Vitro and in Vivo - Biosynthesis and Clearance . Other Physiological Aspects of Fibrinogen - Subject Index.

\section{Fibrinogen}

\section{Its Degradation Products, Structure and Function}

\section{Proceedings - Workshop on Fibrinogen} July 9-10, 1983, Stockholm, Sweden

Editor A. Henschen

To be published in December 1983.17 cm x $24 \mathrm{~cm}$. Approx. 400 pages.

Numerous illustrations. Hardcover. ISBN 3110098067

Contents (Main chapters)

Fibrinogen and Fibrin-Structure - Biosynthesis - Fibrinogen-Fibrin Conversion - Platelet Fibrinogen . Genetically Abnormal Fibrinogens - Fibrinogen in Liver Disease - Interaction with Thrombin and some other Enzymes - Biologically Active Degradation Products - Immunological Aspects - Effect on Plasminogen Activation - Interaction with Platelets and Endothelial Cells - Author- and Subject Index. 
Complete automation of this technique gives it rapidity (50 determinations per hour) and precision which are both very satisfactory.

\section{References}

1. Campbell, D. M. (1962) Biochem. J. 82, 34. Abstract.

2. Hill, P. G. \& Sammons, H. G. (1966) Clin. Chim. Acta 13, 739-745.

3. Persijn, J. P., van der Slik, W. \& Bon, A. W. N. (1969) Z. Klin. Chem. Klin. Biochem. 7, 493-497.

4. Ismail, A. A. A. \& Williams, D. G. (1974) Clin. Chim. Acta $55,211-216$.

5. Kalckar, H. M. (1947) j. Biol. Chem. 165, 445-459.

6. Persijn, J. P., van der Slik, W., Kramer, K. \& de Ruister, C. A. (1968) Z. Klin. Chem. Klin. Biochem. 6, 441-446.

7. Belfield, A., Graham, E. \& Goldberg, D. M. (1970) Clin. Chem. 16, 396-401.

8. Ellis, G., Belfield, A. \& Goldberg, D. M. (1969) Enzymol. Biol. Clin. 10, 349-Abstract.

9. Bootsma, J., Wolthers, B. G. \& Groen, A. (1972) Clin. Chim. Acta 41, 219-222.

10. Goldberg, D. M. \& Ellis, G. (1972) J. Clin. Pathol. 25, 907909.

\section{Acknowledgement}

We are extremely grateful to Mrs. M. Martel for her skilful technical ássistance.

11. Dooley, J. F. \& Racich, L. (1980) Clin. Chem. 26, 12911297.

12. Heinz, F., Pilz, R., Reckel, S., Kalden, J. R. \& Haeckel, R. (1980) J. Clin. Chem. Clin. Biochem 18, 781-788.

13. Mousson, B., Desjacques, P. \& Baltassat, P. (1983) Enzyme (in press)

14. Mousson, B., Allegret, C. \& Baltassat, P. (In préparation).

15. Gentry, M. \& Olson, R. A. (1975) Anal. Biochem. 64, 624627.

16. Joncquiert, F., Nyssen, M., Plumet, A. \& Dorche, J. (1972) Clin. Chim. Acta 42, 361-372.

17. Fox, I. H. (1978) Degradation of purine nucleosides. In "Uric acid" (Kelley, W. N. \& Weiner, I. M., eds.) SpringerVerlag, Berlin, Heidelberg, New-York. pp. 93-124.

18. Smythe, H. A. (1977) Arthr. Rheum. 20, 135-136.

19. Ramsdell, C. \& Kelley, W. N. (1973) Ann. Intern. Med. 78, 239-242.
M. Vernet-Nyssen

Laboratoire de Biochimie

Hôpital de la Croix-Rousse

F-69317 Lyon Cedex 1

France 


$$
\text { 。 }
$$$$
\text { 。 }
$$ 